РЯБЕЦЬ О.М.

\title{
ДО ПИТАННЯ ПРО ВИЗНАЧЕННЯ ДІЯЛЬНОСТІ ЮРИДИЧНИХ КОМПАНІЙ В УКРАЇНІ ЯК ОБ'ЄКТА АДМІНІСТРАТИВНО-ПРАВОВИХ ВІДНОСИН
}

У статті здійснено спробу визначити, чи є об'єктом адміністративно-правових відносин діяльність юридичних компаній в Україні. Автор вважає, що адміністративно-правові відносини, як невід’ємна складова частина вітчизняної адміністративної науки, були, є та будуть предметом наукових досліджень, здебільшого саме дискусійних. Відзначено, що в умовах глобальних трансформацій вітчизняне адміністративне право видозмінюється, про що свідчить перехід від тотального врегульовчого його сприйняття до аспектів служіння народу. У таких умовах аналізована категорія потребує перегляду, зокрема її особливостей, у тому числі і в об'єктному полі складових частин. Відповідно, автор присвятив цій тематиці дану наукову працю на прикладі аналізу діяльності юридичних компаній в Україні.

Стверджується, що, з одного боку, діяльність юридичних компаній - це різновид ведення бізнесу, орієнтованого на отримання прибутку; з іншого - це надання фізичним та юридичним особам можливості реалізації свого конституційного права на отримання юридичної допомоги з різноманітних питань, пов'язаних як із захистом прав, свобод та інтересів таких осіб, так і з бажанням попередити виникнення несприятливих наслідків неправильно обраного вектора дії в повсякденному житті шляхом надання відповідної юридичної послуги.

Із розумінням того, що адміністративно-правові відносини мають досить широке коло різновидів, визначено, що діяльність юридичних компаній в Україні може бути об'єктом таких відносин у разі ії публічного адміністрування, зокрема: у процесі легалізації таких осіб, у тому числі отримання дозвільних документів, державної реєстрації та подальшого оподаткування прибутків; під час регулювання ринку надання юридичних послуг в Україні та державного стратегічного планування розвитку вітчизняної економіки.

Ключові слова: адміністративно-правові відносини, об'єкт, суб'єкт, юридична діяльність, юридичний бізнес, юридичні компанії, юридичні послуги.

The article attempts to determine whether the activities of law firms in Ukraine are an object of administrative-legal relations. The author believes that administrative and legal relations, as an integral component of the domestic administrative science, have been, will be and will be the subject of scientific research, and mainly discussion ones. It is noted that in the context of global transformations, domestic administrative law is changing, as evidenced by the transition of its perception from total regulation to aspects of serving the people. In such conditions, the category in question requires a review, in particular of its features, including the components in the object field. Accordingly, the author devoted this research work to this topic on the example of analysis of the activities of law firms in Ukraine.

It is argued that, on the one hand, the activities of law firms are a form of running a profit-oriented business; on the other, it provides individuals and legal entities with the opportunity to exercise their constitutional right to receive legal assistance on various issues related to the protection of the rights, freedoms and interests of such persons, such as the desire to prevent the occurrence of adverse consequences of an incorrectly chosen vector of action in everyday life by providing relevant legal services.

With the understanding that administrative-legal relations have a fairly wide range of varieties, it is determined that the activities of law firms in Ukraine can be the subject

(С РЯБЕЦЬ О.М. - здобувач (Науково-дослідний інститут публічного права) 
of such relations in the case of its public administration, in particular: in the process of legalizing such persons, including obtaining permits, state registration and further taxation of income; in regulating the market for the provision of legal services in Ukraine and state strategic planning for the development of the domestic economy.

Key words: administrative and legal relations, legal activity, legal business, legal companies, legal services, object, subject.

Вступ. Усе те, на що спрямовані суб'єктивні права та юридичні обов'язки учасників правовідносин, іншими словами, те, із приводу чого виникло саме правовідношення, традиційно вважається об'єктом таких відносин. Але в будь-якому разі об'єкт публічних правовідносин $є$ категорією сталою, а не динамічною. Навколо об'єкта, що перебуває у статичному стані, відбуваються дії, події, реалізовуються права та обов'язки, що стосуються конкретних суб'єктів [1, с. 114].

Більше того, в умовах глобальних трансформацій вітчизняне адміністративне право видозмінюється, про що свідчить перехід від тотального врегульовчого його сприйняття до аспектів служіння народу. Відповідно, в таких умовах і категорія «адміністративно-правові відносини» має свої особливості, в тому числі і в об'єктному полі їхніх складових частин.

Із метою визначення, чи є об'єктом адміністративно-правових відносин діяльність юридичних компаній в Україні, вважаємо за необхідне присвятити цій тематиці дану наукову працю.

Огляд останніх досліджень. Адміністративно-правові відносини, як невід’ємна складова частина вітчизняної адміністративної науки, були, є та будуть предметом наукових досліджень, здебільшого саме дискусійних. Як зазначено вище, трансформаційні зміни вимагають перегляду категоріального апарату, віднайдення оптимальних шляхів розвитку окремих одиниць, пояснення існування певних явищ та процесів. Зокрема, праці вчених, що розкривають окремі аспекти зазначеного, змодеровані В. Авер'яновим, Ю. Битяком, В. Галуньком та багатьма іншими провідними адміністративістами.

У свою чергу, до питання про особливості діяльності юридичних компаній в Україні звертали свої наукові погляди такі вчені, як: Н. Геселева, Р. Колесник, В. Малига, В. Малишко, О. Марченко, І. Марчук, Т. Миськевич, Н. Михальчишин, А. Родюк, Ю. Сахарова, В. Сеник, О. Хохуляк, Р. Чумак та інші. Однак спеціалізованого розгляду заявленої нами проблематики вітчизняна адміністративна наука не має, а вищевказані вчені заклали фундамент для реалізації зазначеного.

Виклад основних положень. Перехід економіки України на ринкову модель управління сприяв підвищенню ролі договору як правового засобу регулювання суспільних відносин, що виникають у всіх сферах суспільного життя. Сфера послуг $є$ однією з найперспективніших галузей економіки, яка розвивається надзвичайно швидкими темпами. Вона охоплює широке поле діяльності - від торгівлі і фінансування до страхування та посередництва. Переважна більшість організацій певною мірою надає послуги. I чим більше ускладнюється виробництво і насичується ринок товарами, тим більше зростає попит на послуги. Сфера послуг випереджає виробничу сферу за темпами розвитку і появою нових видів послуг, які пристосовані до потреб ринку і споживачів. Процентне співвідношення кількості наданих у суспільстві послуг $є$ індикатором рівня економічного розвитку суспільства [2, с. 114$]$.

Наразі юридичні послуги є одним із найпопулярніших різновидів послуг серед фізичних та юридичних осіб [3]. Відповідно, і практика забезпечення громадян кваліфікованою юридичною допомогою в сучасному демократичному суспільстві має надзвичайно важливе соціально-політичне значення [4].

Зокрема, це можна зумовити тим, що право кожного на правову допомогу є конституційно закріпленим та передбачає можливість фізичної особи одержати юридичні (правові) послуги. Шляхом закріплення цього права в Основному Законі держава створила всі передумови для розвитку можливостей отримання і надання юридичних послуг у різних сферах правовідносин, створення спеціальних правових механізмів забезпечення і реалізації права на юридичну допомогу $[5 ; 6$, с. 85$]$.

Уточнимо, що ринок юридичних послуг - це сукупність операцій, де об'єктом виступають певні професійні дії фахівців із права з надання юридичної допомоги юридичним та фізичним особам на комерційній основі. Він представляє собою соціально-економічний механізм, який забезпечує прийняття та передавання прав власності на об'єкт купівлі-продажу - юридичну послугу [7, с. 76]. 
Причому специфіка розвитку юридичного ринку в України полягає в поступовому трансформуванні діяльності юридичних компаній, юристів та адвокатів із суто професійної діяльності у діяльність із ведення саме юридичного бізнесу. Безумовно, юридичний бізнес, як і інші види підприємницької діяльності, має загальні риси та окремо свої конкретні особливості [8].

3-поміж іншого зазначимо, що суб'єктами ринку юридичних послуг є 1) споживачі (замовники), метою яких є вирішення певних проблем за допомогою 2) фахівців із права (вітчизняні юридичні фірми різних форм власності, спеціалізовані й багатогалузеві за спрямованістю практичної юридичної діяльності відповідно до галузей права та видів ділової активності; філіали та представництва транснаціональних юридичних компаній, фірми з іноземним капіталом; приватні юристи - суб'єкти підприємницької діяльності; юридичні консультації обласних колегій адвокатів; консалтингові фірми, для яких юридичні послуги є одним із видів ділових послуг; консультативні підрозділи вищих юридичних навчальних закладів, що надають юридичну допомогу фізичним та юридичним особам на комерційній основі; фахівці права, для яких здійснення певних дій із юридичної допомоги та надання платних професійних юридичних порад не $є$ головним видом професійної діяльності) [7, с. 76].

До речі, розвиток ринку юридичних послуг є однією з головних ознак цивілізованого суспільства, вирішальною передумовою стабільності економічної системи на загальнонаціональному та регіональному рівнях, гарантує узгодженість реформ із наявними стратегічними пріоритетами [9, с. 142]. Зокрема, якби кожен рік потрібно було б умовно назвати одним словом, яке характеризує розвиток юридичного бізнесу, то 2018 р. отримав би назву «рік трансформацій». Адже в цьому році відбулися значні зміни в бізнесі, практиках, взаємовідносинах «клієнт - юридична компанія», підходах до позиціонування, а також у ставленні до інновацій. Лідери ринку говорять про певне пожвавлення економіки та ринку загалом, активізацію інвестування в перспективні сфери (наприклад, у нерухомість та альтернативну енергетику). Звичайно, підгрунтя для цього заклала державна політика та процеси реформування в нашій країні [10].

За підрахунками команди Dead Lawyers, доходи юридичних компаній за 2018 рік були такими: «Baker McKenzie» - 416850700 грн.; «Asters» - 565895100 грн.; «Sayenko Kharenko» 348649300 грн.; «Lexwell\&Partners» - 324795000 грн.; «DLA Piper Ukraine» - 211256000 грн.; «Ілляшев і Партнери» - 136096000 грн.; «Aeqou» - 153773600 грн.; «Arzinger» - 142863100 грн.; «Василь Кісіль і Партнери» - 110846200 грн.; «CMS» - 108411800 грн.; «AVELLUM» 89140400 грн.; «Integrites» - 96989900 грн.; «Redcliffe Partners» - 85948000 грн.; «Evris» 107495100 грн.; «Алєксєєв, Боярчуков і Партнери» - 96209200 грн.; «Дубинський і Ошарова» - 72432300 грн.; «Kinstellar» - 76411800 грн.; «Dentons» - 67032000 грн.; «Пахаренко і Партнери» - 49582700 грн.; «АНК» - 48871600 грн.; «Юридична група LCF» - 50359000 грн.; «Eterna Law» - 36744600 грн.; «EY» - 30921000 грн.; «GOLAW» - 28138300 грн.; «Шкребець і Партнери» - 50988100 (2017 рік) грн.; «JUSCUTUM» - 28156500 грн.; «MORIS GROUP» 16826100 грн.; «Салком»-16 524000 грн.; «Антіка»-14642 100 грн.; «Юрлайн»-15885900 грн.; «ADER HABER» - 13792100 грн.; «VB PARTNERS» - 12495600 грн.; «Alexandrov \& Partners» 17172200 грн.; «Interlegal» - 9751900 грн.; «EVERLEGAL»- 16310100 грн.; «AVER LEX» 9274100 грн.; «Pavlenko Legal Group» - 14593500 (2017 рік) грн.; «Соколовський і Партнери» - 5525400 грн.; «Юридична група EUCON» - 4245500 грн.; «Династія» - 5658600 грн.; «Barristers» - 3488400 грн.; «Коннов і Созановський» - 4306900 грн.; «Грамацький і Партнери» - 4354500 грн.; «КМ Партнери» - 4682300 грн.; «Lavrynovych \& Partners» - 3199400 грн.; «L.I.GROUP» - 1375400 грн.; «Gryphon Legal» - 3292100 грн.; «KPMG Law Ukraine» 2937400 грн.; «ILF»-2 080800 грн.; «EQUITY» - 1293700 грн. [11].

Наведені рейтингові дані про обсяг доходів не свідчать про якість юридичної послуги або репутацію юридичної фірми на ринку, однак репрезентують загальний попит на послугу та рівень конкуренції в даному секторі бізнес-індустрії.

Зрозумілим є те, що в більшості із зазначених суб'єктів існує своя сфера діяльності, в якій їм немає рівних, адже тільки таким чином можна стати найкращим навіть у вузькому направленні, створити свій образ і завоювати авторитет. Водночас існує декілька направлень юридичної діяльності, якими займаються практично всі універсальні фірми, - безпрограшні варіанти. Наприклад, останній рік підкреслив значення судової практики - вона завжди була, $є$ і буде затребувана клієнтами, а це означає - регулярно і постійно приноситиме прибуток. Якщо аналізувати найбільш поширені види спеціалізацій юридичних компаній у цілому, то можна спостерігати таку картину: судова справа (93\%), потім господарське право (91\%), корпоративне право (90\%), податкове право (82\%), і замикає п'ятірку лідерів нерухомість, будівництво і земельне право $[12$, с. $115 ; 13$, с. 77$]$. 
Отже, із зазначеного стає зрозумілим, що не вимагає додаткового обгрунтування тезис про те, що основою діяльності юридичних компаній є надання відповідних послуг замовнику, який потребує професійної юридичної допомоги з різноманітних питань.

Уточнимо, що законодавством України розрізняються два види правових послуг: юридичні послуги та адвокатські послуги (допомога). У ст. 5 Закону України «Про соціальні послуги» зазначено, що під юридичними послугами слід розуміти надання консультацій із питань чинного законодавства, здійснення захисту прав та інтересів осіб, які перебувають у складних життєвих обставинах, сприяння застосуванню державного примусу і реалізації юридичної відповідальності осіб, які вдаються до протиправних дій щодо цієї особи (оформлення правових документів, адвокатська допомога, захист прав та інтересів особи тощо) [14]. Тому можна зробити висновок, що адвокатська допомога $є$ одним із видів юридичних послуг [2, с. 114], однак має свою специфіку.

Дещо спірним в означеній площині є питання, чи відноситься діяльність адвокатів саме до бізнес-індустрії. 3 одного боку, це професійна діяльність, надання якої передбачає грошову винагороду, а з іншого - мистецтво, тобто спосіб «творити» справедливість, відстоювати конституційні права, свободи та інтереси пересічних громадян. Ми - прибічники думки, що адвокатура як інститут захисту є місіонним, передбачає доступ до професії виключно високоосвічених людей із наявним багажем таких морально-етичних якостей, які унеможливлюють зловживання власними вигодовими інтересами. На жаль, в Україні ми маємо змогу спостерігати дуалістичну модель даного явища, де більшість адвокатів справді діють «на благо», вірять у свою професію та реалізовують ії з честю й гідністю, а інші - йдуть бізнес-шляхом. Це право кожного, однак слід пам'ятати, що зроблений вибір впливає на весь інститут адвокатури і тим самим унеможливлює однозначність вирішення зазначеного питання.

Однак у будь-якому разі головна мета будь-якого юриста чи адвоката - захист інтересів і прав свого клієнта, в тому числі і в суді. При цьому не завжди професійна правова допомога потрібна лише у складних життєвих ситуаціях. Найчастіше юридичні послуги потрібні в повсякденному житті, наприклад, у випадку розлучення або суперечки з банком. Допомога досвідченого фахівця в галузі права надає можливість вирішити проблему швидко і ефективно [3].

Водночас для споживачів юридичних послуг одною з найважливіших речей $є$ не тільки професіоналізм, але й індивідуальний підхід у спілкуванні з клієнтом, а саме спілкування за телефоном, швидкість виконання завдань, ведення індивідуальних особистих розмов, прийняття клієнта тощо [15]. Відповідно, під час надання юридичних послуг не лише з'ясовується конкретне завдання, яке ставить клієнт перед виконавцем, а й уточнюються строки виконання завдання та бажаний кінцевий результат - з одного боку; а з іншого - встановлюється психологічний портрет клієнта для вироблення тактики спілкування та взаємодії з ним [16, с. 239].

Для правильної реалізації зазначеного існують певні етичні вимоги та обмеження, що застосовуються в підприємницькій діяльності з надання юридичних послуг. За переконаннями В. Малиги та В. Станкевича, їх можна систематизувати залежно від спрямованості впливу на безпосереднього споживача, розділивши їх на сім груп: 1) правила професійного надання юридичних послуг; 2) правила рекламування юридичних послуг; 3) правила попередження неетичної поведінки; 4) правила формування (вибору) найменування; 5) правила оплати юридичних послуг; 6) правила доступності юридичних послуг; 7) правила дострокового припинення надання юридичних послуг [17, с. 153].

Окремо зазначимо, що в певних умовах, які визначаються зовнішніми і внутрішніми національними і міжнародними чинниками, юридичний консалтинг може мати негативний вплив на формування правової економіки. Мається на увазі діяльність надавачів юридичних послуг, яка формально є практичною професійною діяльністю з надання правової допомоги, однак реально спрямована на задоволення попиту клієнтів на послуги, пов'язані зі сприянням у вирішенні їхніх проблем методами, що суперечать професійним та етичним нормам юридичної діяльності, а в певних випадках - i нормам права. Такі юридичні фірми пропонують на ринку неякісні юридичні послуги, спираючись на ціновий демпінг, залучають клієнтів низькою ціною, що завдає значного матеріального і морального збитку фахівцям, які надають високоякісні юридичні послуги. Це зумовлено тим, що ринок юридичного консалтингу характеризується асиметричним розподілом інформації та наявністю значних інформаційних переваг у продуцентів юридичних послуг. Юрист чи юридична фірма, маючи найбільш повну інформацію про послугу, можуть приховувати від клієнта дійсні цілі своєї поведінки, орієнтуючись на одержання від угоди однобічних вигод. Наслідком цього може бути виникнення ситуації некоректного (несприятливого) відбору, що становить вибір послуги клієнтом за критерієм ціни як імовірних витрат на правову допомогу, оскільки через неповноту інформації він не може диференціювати продуцентів 
за критерієм якості юридичної послуги. У цьому випадку ринку юридичних послуг можуть бути властиві характеристики моделі ринку «лимонів» Дж. А. Акерлофа [18]: оскільки ринкова ціна виявляється занадто низькою, асиметрія інформації призводить до втрат фахівців, що надають юридичні послуги високої якості, і до їх виходу з ринку [19, с. 59].

Висновки. Усе вищевикладене дає можливість сформулювати висновок, згідно з яким, 3 одного боку, діяльність юридичних компаній - це різновид ведення бізнесу, орієнтованого на отримання прибутку; з іншого - це надання фізичним та юридичним особам можливості реалізації свого конституційного права на отримання юридичної допомоги з різноманітних питань, пов'язаних як із захистом прав, свобод та інтересів таких осіб, так і з бажанням попередити виникнення несприятливих наслідків неправильно обраного вектора дії в повсякденному житті шляхом надання відповідної юридичної послуги.

Із розумінням того, що адміністративно-правові відносини мають досить широке коло різновидів, вважаємо, що діяльність юридичних компаній в Україні може бути об'єктом таких відносин у разі ії публічного адміністрування, зокрема: у процесі легалізації таких осіб, у тому числі отримання дозвільних документів, державної реєстрації та подальшого оподаткування прибутків; під час регулювання ринку надання юридичних послуг в Україні та державного стратегічного планування розвитку вітчизняної економіки.

\section{Список використаних джерел:}

1. Литвин І. Об'єкти адміністративно-правових відносин у сфері надання освітніх послуг. Підприємництво, господарство і право. 2016. № 6. С. 114-118.

2. Малишко В.М., Сеник В.О. Правове регулювання діяльності з надання правових послуг. Актуальні питання публічного та приватного права. 2014. № 3. С. 113-117.

3. Які послуги надають юристи і адвокати. Інформаційний портал міста Дубно. 2019. URL : http://03656.com.ua/yaki-poslugi-nadayut-yuristi-i-advokati/.

4. Миськевич Т. Реформування ринку юридичних послуг в Україні. Центр досліджень сочіальних комунікацій; Національна юридична бібліотека НБУВ: URL : http://nbuviap.gov.ua/ index.php?option $=$ com_content\&view $=$ article\&id=1207:reformuvannya-rinku-yuridichnikh-poslugvukrajini\&catid $=8 \&$ Itemid $=350$.

5. Конституція України : Закон України від 28.06.1996 № 254к/96-ВР. Відомості Верховної Ради України. 1996 р. № 30. Стаття 141.

6. Марчук І.Ф. Юридичні послуги і юридична допомога: проблеми розмежування. Часопис Київського університету права. 2012. № 1. С. 84-87.

7. Геселева Н.В. Огляд ринку юридичних послуг в Україні. Вісник Київського національного університету технологій та дизайну. Серія : Економічні науки. 2015. № 6. С. 75-80.

8. Чумак Р. Особливість середовища «юридичного» бізнесу. ARESLEX. URL : https://areslex.com/blog/521-osoblivist-seredovishcha-yuridichnogo-biznesu.

9. Хохуляк О.О. Ринок юридичних послуг сполучених штатів Америки: особливості становлення та тенденції розвитку. Науковий вісник Ужгородського національного університету. Серія : Міжнародні економічні відносини та світове господарство. 2016. Вип. 7(3). С. 142-146.

10. Родюк А. Юридичний бізнес: Що було, що буде, чим серце заспокоїться. «Юридична газета». 2018. URL : http://yur-gazeta.com/publications/legal-business-in-ukraine/yuridichniybiznes-shcho-bulo-shcho-bude-chim-serce-zaspokoyitsya.html.

11. ТОП-50 юридичних фірм України за версією Dead Lawyers Society (перелік). 2019. LegalHub. URL : https://legalhub.online/advokatska-diyalnist/top-50-yurydychnyh-firm-ukrayiny-zaversiyeyu-dead-lawyers-society-perelik/.

12. Колесник Р. Юридические фирмы Украины. Ежегодное обозрение рынка юридических услуг. 2013. № 13-0511. 198 с.

13. Геселева Н.В. Огляд ринку юридичних послуг в Україні. Вісник Київського національного університету технологій та дизайну. Серія : Економічні науки. 2015. № 6. С. 75-80.

14. Про соціальні послуги : Закон України від 19.06.2003№966-IV. Верховна Рада Украӥни. URL : http://zakon4. rada.gov.ua/laws/show/966-15.

15. Сахарова Ю. Спираючись на власний досвід, можу запевнити: немає безнадійних справ. Закон і бізнес. 2013. URL : https://zib.com.ua/ua/15379-zastupnik_golovi_naau_valentin_ gvozdiy_spirayuchis_na_vlasni.html.

16. Михальчишин Н.Л. Сутність прояву конкуренції на ринку юридичних послуг. Вісник сочіально-економічних досліджень. 2014. Вип. 1. С. 237-244. 
17. Малига В.А. Етичні засади підприємницької діяльності з надання юридичних послуг. Європейські перспективи. 2013. № 1. С. 151-159.

18. Акерлоф Дж. Рынок «лимонов»: неопределенность качества и рыночный механізм. THESIS. 1994. Вып. 6. С. 91-104.

19. Марченко О.С. Деструкції національного ринку юридичних послуг: зміст та наслідки для формування правової економіки. Економічна теорія та право. 2016. № 2. С. 57-66.

УДК 342.951: 61 (477)

DOI https://doi.org/10.32844/2618-1258.2019.6.39

СІДЕЛКОВСЬКИЙ О.Л.

\section{УДОСКОНАЛЕННЯ ЄДИНОГО МЕДИЧНОГО ПРОСТОРУ УКРАЇНИ: КЛЮЧОВІ ОРГАНІЗАЦІЙНО-ПРАВОВІ КРОКИ}

Стаття присвячена проблемам організаційно-правових основ єдиного медичного простору України. Нині активно обговорюється питання правового забезпечення медичної реформи, що є невід'ємною частиною впровадження та належного функціонування єдиного медичного простору. Цей вид реформи слід проводити належним чином, враховуючи пріоритет забезпечення та захисту прав, свобод і законних інтересів пацієнтів - «ядро» системи охорони здоров'я, об'єкт позитивних зусиль відповідних органів влади. Звертається увага на фактори, які роблять проблему актуальною. Зокрема, констатується незадовільний стан щодо прав пацієнтів стосовно наявності медичної допомоги. Зроблено висновок про необхідність комплексних дій відповідних органів. Доведено, що під час удосконалення правової бази та забезпечення пріоритетного розвитку на засадах сімейної медицини, реструктуризації галузі, упорядкування мережі, структури та функцій закладів охорони здоров'я, опрацювання медичних стандартів, створення системи забезпечення і контролю якості медичної допомоги, створення системи інформаційного забезпечення тощо цілком можливо реалізувати стратегію ефективного державного управління у сфері охорони здоров'я, стрижнем якої є створення конкурентоздатних регіонів і самодостатніх територіальних громад для забезпечення територіально цілісного та збалансованого розвитку. Із критичного відображення поглядів автора випливає таке: по-перше, незадовільний стан охорони здоров’я в Україні, який є своєрідним фоном, на основі якого формується єдиний медичний простір; по-друге, територіальний принцип медичної допомоги не повинен бути абсолютизованим, його слід поступово удосконалювати; по-третє, медицина в погонах (Міністерство оборони, Міністерство внутрішніх справ, Служба безпеки, Державна прикордонна служба тощо) та цивільна медицина повинні поступово рухатися назустріч одна одній: в організаційному, правовому та соціальному розумінні; по-четверте, негативна демографічна ситуація у країні повинна слугувати «мотиватором» для внесення відповідних змін, спрямованих на поліпшення доступності допомоги через створення єдиного медичного простору.

Ключові слова: єдиний медичний простір, медичне право, охорона здоров'я, принципи правового регулювання, права пацієнтів.

The article is devoted to the problems of organizational and legal foundations of the single medical space of Ukraine. At present, the issue of legal support for medical reform, which is an integral part of the introduction and proper functioning of the single medical space, is actively discussed. This kind of reform should be done in a proper

( СІДЕЛКОВСЬКИЙ О.Л. - кандидат медичних наук, директор (Клініка «Аксімед») 